\title{
PENGARUH KOREKSI ATENUASI RADAR CUACA TERHADAP PERHITUNGAN ESTIMASI CURAH HUJAN DI JAWA TIMUR
}

\author{
EFFECT OF WEATHER RADAR ATENUATION CORRECTION \\ ON RAIN ESTIMATION CALCULATIONS IN EAST JAVA
}

\author{
Ahmad Kosasih, Hartono, dan Retnadi Heru Jatmiko \\ Fakultas Geografi, Universitas Gadjah Mada \\ Submitted:15-01-2020; Revised: 04-08-2021; Accepted: 31-05-2021
}

\begin{abstract}
Rainfall estimation using band $C$ weather radar creates uncertainty in the results of its estimation accuracy. The cause is meteorological and non-meteorological disturbances that affect the reflectivity raw data $(\mathrm{dBz})$, one of which is attenuation due to rain, especially with heavy and very heavy intensity. This study aims to evaluate the attenuation correction ability of the reflectivity raw data generated by the weather radar against the calculation of rainfall estimates at the Juanda Sidoarjo Meteorological Station, as well as the best attenuation correction coefficient to be applied in the processing of rainfall estimates by weather radar. The method used to perform attenuation correction is Z-based attenuation correction (ZATC). The calculation of attenuation correction using the ZATC method uses several $a$ and $\beta$ coefficients while the $Z-R$ relation $\left(Z=200 R^{1.6}\right)$ is used to calculate the estimated rainfall before and after attenuation correction. The results showed that the attenuation correction of the $C$ band weather radar reflectivity raw data was able to provide an increase in the accuracy of rainfall estimation where in the estimation of rainfall from a weather radar without the attenuation correction stage of the raw data, an accuracy value of $70.8 \%$ was obtained, while applying the attenuation correction using several The a and $\beta$ coefficients obtained an increase in the accuracy of rainfall estimation between $72.5 \%$ to $86.9 \%$. The best a and $\beta$ coefficients for attenuation correction of weather radar reflectivity $(\mathrm{dBz})$ can be applied in obtaining a more accurate rainfall estimate, namely the $a$ and $\beta$ coefficients according to Krämer and Verworn which are able to provide an increase in the accuracy of rainfall estimation by $16.1 \%$.
\end{abstract}

Keywords: Attenuation; Remote sensing; Rainfall; Reflectivity; Weather radar.

\begin{abstract}
ABSTRAK
Estimasi curah hujan menggunakan radar cuaca band $\mathrm{C}$ memunculkan ketidakpastian pada hasil akurasi estimasinya. Penyebabnya adalah gangguan meteorologi dan non meteorologi yang mempengaruhi raw data reflektivitas $(\mathrm{dBz})$, salah satunya yaitu atenuasi karena hujan terutama dengan intensitas lebat dan sangat lebat. Penelitian ini bertujuan untuk mengevaluasi kemampuan koreksi atenuasi pada raw data reflektivitas yang dihasilkan oleh radar cuaca terhadap perhitungan estimasi curah hujan di Stasiun Meteorologi Juanda Sidoarjo, serta koefisien koreksi atenuasi mana yang terbaik untuk dapat diterapkan di dalam pengolahan estimasi curah hujan oleh radar cuaca. Metode yang digunakan untuk melakukan koreksi atenuasi yaitu Z-based attenuation correction (ZATC). Perhitungan koreksi atenuasi dengan metode ZATC menggunakan beberapa koefisien a dan $\beta$ adapun relasi $Z-R\left(Z=200 R^{1.6}\right)$ digunakan
\end{abstract}

*Corresponding author:kosasih.bmkg@gmail.com

Copyright $\odot 2021$ THE AUTHOR(S).This article is distributed under a Creative Commons Attribution-Share Alike 4.0 International license. Jurnal Teknosains is published by the Graduate School of Universitas Gadjah Mada. 
untuk perhitungan estimasi curah hujan sebelum dan sesudah dilakukan koreksi atenuasi. Hasil penelitian menunjukkan bahwa koreksi atenuasi terhadap raw data reflektivitas radar cuaca band C mampu memberikan peningkatan akurasi estimasi curah hujan dimana pada estimasi curah hujan dari radar cuaca tanpa dilakukan tahapan koreksi atenuasi terhadap raw data diperoleh nilai akurasi sebesar $70.8 \%$ sedangkan dengan menerapkan koreksi atenuasi menggunakan beberapa koefisien a dan $\beta$ diperoleh peningkatan akurasi estimasi curah hujan antara $72.5 \%$ sampai dengan $86.9 \%$. Nilai koefisien a dan $\beta$ untuk koreksi atenuasi raw data reflektivitas ( $\mathrm{dBz}$ ) radar cuaca yang terbaik untuk dapat diterapkan dalam memperoleh estimasi curah hujan yang lebih akurat yaitu dengan koefisien a dan $\beta$ menurut Krämer dan Verworn yang mampu memberikan peningkatan akurasi estimasi curah hujan sebesar $16.1 \%$.

Kata Kunci: Atenuasi; Curah hujan; Penginderaan jauh; Radar cuaca; Reflektivitas.

\section{PENGANTAR}

Estimasi curah hujan secara kuantitatif dengan menggunakan radar cuaca merupakan suatu proses yang sangat kompleks. Ada banyak sumber gangguan saat proses pengamatan oleh radar cuaca baik meteorologi (atenuasi, bright band echo) dan nonmeteorologi (clutter, signal propagation) yang dapat mempengaruhi kualitas raw data radar cuaca, sehingga menyebabkan ketidakpastian hasil estimasi curah hujan dari radar cuaca (Harrison, Driscoll and Kitchen, 2000). Untuk memperoleh raw data (data mentah) yang berkualitas sebagai hasil pengamatan radar cuaca maka sangat perlu dilakukan proses koreksi sebelum diolah dengan sejumlah algoritma untuk menghasilkan informasi estimasi curah hujan (Friedrich, Hagen and Einfalt, 2006). Beberapa metode yang telah diterapkan para peneliti dalam memperbaiki kualitas raw data reflektivitas radar adalah mengkoreksi raw data reflektivitas dengan beberapa jenis koreksi di antaranya yaitu koreksi clutter (Hannesen \& Loffler-Mang, 1998; Gabella \& Notarpietro, 2002; Hubbert et al., 2009), attenuation (Hitschfeld \& Bordan, 1954; Atlas \& Ulbrich, 1977; Olsen et al., 1978; Bringi et al., 1990; Harrison et al., 2000; Bringi et al., 2001; Krämer \& Verworn, 2008), dan bright band (Smith, 1986; Kitchen et al., 1994; Hardaker et al., 1995). Adapun koreksi yang akan diterapkan pada raw data reflektivitas radar cuaca band C di Stasiun Meteorologi Juanda yaitu metode koreksi atenuasi (attenuation) Z-based attenuation correction (ZATC) yang dikembangkan Hitschfeld dan Bordan dengan koefisien a dan $\beta$ menurut Battan, Harrison serta Krämer dan Verworn sebelum proses perhitungan estimasi curah hujan menggunakan persamaan model relasi Z-R Marshall-Palmer, sehingga hasil yang diharapkan yaitu adanya peningkatan akurasi estimasi curah hujan yang dihasilkan oleh radar cuaca tersebut. Hujan merupakan objek utama yang diamati oleh radar cuaca, sekaligus merupakan sumber utama yang menyebabkan ketidakpastian di dalam mengestimasi curah hujan dengan radar cuaca band $\mathrm{C}$ terutama hujan dengan intensitas lebat (Jacobi and Heistermann, 2016). Ketidakpastian tersebut diakibatkan adanya gangguan berupa atenuasi oleh hujan yang menyebabkan pelemahan energi pulsa radar yang diterima oleh receiver pada sistem radar cuaca. Besarnya pelemahan energi tergantung terhadap intensitas curah hujan, jarak objek hujan dengan radar cuaca, dan panjang gelombang radar yang digunakan.

Semakin lebat intensitas curah hujan dan semakin pendek panjang gelombang yang digunakan oleh radar cuaca maka nilai atenuasi yang mempengaruhi raw data reflektivitas $(\mathrm{dBz})$ radar akan semakin besar (Jacobi and Heistermann, 2016). Raw data reflektivitas yang tidak terkoreksi akan menambah ketidakpastian dalam perhitungan estimasi curah hujan oleh sistem radar cuaca sehingga pada akhirnya akan berpengaruh terhadap kualitas informasi cuaca publik maupun peringatan dini cuaca ekstrim. Operasional radar cuaca band C di Stasiun Meteorologi Juanda saat melakukan proses estimasi curah hujan belum dilakukan koreksi atenuasi terhadap raw data reflektivitas maupun koreksi gangguan meteorologi dan nonmeteorologi lainnya, sebatas melakukan filter terhadap sinyal radar cuaca yang diterima oleh receiver.

Hujan merupakan salah satu fenomena cuaca yang dapat diamati intensitasnya melalui dua cara 
yaitu pengukuran langsung dan tidak langsung (Munawar, 2016; WMO, 2017). Pengamatan curah hujan secara langsung dilakukan dengan menggunakan alat penakar curah hujan manual maupun penakar otomatis sementara pengamatan curah hujan secara tidak langsung dilakukan dengan menerapkan teknologi penginderaan jauh seperti satelit dan radar cuaca. Sistem penginderaan jauh tersebut mampu menghasilkan estimasi curah hujan melalui proses perolehan dan pengolahan dengan algoritma tertentu untuk menghasilkan informasi curah hujan, yang dapat menjangkau wilayah secara luas dengan waktu yang relatif lebih cepat.

Radar meteorologi atau radar cuaca mampu memberikan informasi parameter cuaca berupa curah hujan secara kuantitatif serta arah dan kecepatan angin vertikal maupun horizontal. Radar memancarkan gelombang elektromagnetik dalam bentuk pulsa yang dipancarkan melalui antena dengan panjang gelombang tertentu. Gelombang elektromagnetik yang dipancarkan antena secara langsung mengenai target (objek) yang berada pada area beam radar. Perhitungan matematis yang berkaitan dengan target (objek) pada gelombang elektromagnetik radar cuaca terbagi menjadi dua bagian yaitu perhitungan untuk target titik (point target) dan perhitungan untuk target meteorologi (meteorological target) (Rinehart, 2004; Skolnik, 2008; Fukao \& Hamazu, 2014; Rauber \& Nesbitt, 2018). Saat ini, radar cuaca yang dioperasikan Badan Meteorologi Klimatologi dan Geofisika (BMKG) di beberapa lokasi di wilayah Indonesia yaitu sebanyak 37 radar cuaca jenis band $\mathrm{C}$ polarisasi tunggal, satu radar cuaca jenis band $X$ polarisasi tunggal dan tiga radar cuaca jenis band $\mathrm{X}$ dual polarisasi, yang diharapkan akan mampu menunjang pelayanan terhadap publik baik berupa informasi rutin dan informasi peringatan dini (Meteorological Early Warning Sistem, MEWS) (Wardoyo, 2015).

Intensitas curah hujan adalah jumlah curah hujan dalam satu satuan waktu tertentu (Mori, 2003; WMO, 2017). Klasifikasi intensitas curah hujan dapat dilihat pada Tabel 1 berikut ini:

Tabel 1

Klasifikasi intensitas curah hujan menurut Mori, WMO, dan BMKG

\begin{tabular}{|c|c|c|c|c|c|}
\hline \multirow{3}{*}{ Keadaan curah hujan } & \multicolumn{5}{|c|}{ Intensitas curah hujan (mm) } \\
\hline & \multicolumn{2}{|c|}{ Mori (2003) } & \multirow{2}{*}{$\begin{array}{c}\text { WMO (2017) } \\
1 \text { jam }\end{array}$} & \multicolumn{2}{|c|}{ BMKG } \\
\hline & 1 jam & 24 jam & & 1 jam & 24 jam \\
\hline Hujan sangat ringan & $<1$ & $<5$ & - & - & - \\
\hline Hujan ringan & $1-5$ & $5-20$ & $\mathrm{i}<2.5$ & $1-5$ & $5-20$ \\
\hline Hujan normal/ sedang & $5-20$ & $20-50$ & $2.5 \leq \mathrm{i}<10.0$ & $5-10$ & $20-50$ \\
\hline Hujan lebat & $10-20$ & $50-100$ & $10.0 \leq \mathrm{i}<50.0$ & $10-20$ & $50-100$ \\
\hline Hujan sangat lebat/ violent/ ekstrim & $>20$ & $>100$ & $i \geq 50.0$ & $>20$ & $>100$ \\
\hline
\end{tabular}

Sumber: Mori (2003), WMO (2017) dan BMKG (2010)

Terjadinya atenuasi akan mengakibatkan pengurangan kekuatan gelombang elektromagnetik ketika melewati air hujan terutama bagi radar yang memiliki panjang gelombang kurang dari $10 \mathrm{~cm}$ (Rico-ramirez, 2012). Pelemahan kekuatan gelombang elektromagnetik pada radar cuaca band C terjadi meskipun pada hujan intensitas ringan sementara itu penurunan nilai reflektivitas $\left(Z_{H}\right)$ pada radar cuaca dihasilkan oleh gangguan atenuasi akan menyebabkan terjadinya kesalahan ketika mengestimasi curah hujan (Bringi dkk ., 2001; G. Park dkk., 2005). Gangguan atenuasi yang bersumber dari hujan dan terjadi pada saat pengamatan radar cuaca harus dapat diminimalisir dengan menggunakan algoritma koreksi atenuasi sebelum raw data diolah menjadi informasi estimasi curah hujan.

Proses untuk dapat menghilangkan dan atau mengurangi gangguan meteorologi berupa atenuasi yang disebabkan oleh hujan pada raw data reflektivitas radar cuaca band $\mathrm{C}$ sebelum dilakukan tahapan estimasi curah hujan yaitu 
dengan metode Z-based attenuation correction (ZATC) yang dikembangkan Hitschfeld dan Bordan pada tahapan pre-processing untuk koreksi atenuasi terhadap raw data reflektivitas radar cuaca di Stasiun Meteorologi Juanda dengan menggunakan koefisien $a$ dan $\beta$ menurut Battan, Harrison serta Kramer dan Verworn untuk dapat meningkatkan dan memperbaiki akurasi estimasi curah hujan.

Tujuan dari penelitian ini adalah mengevaluasi hasil estimasi curah hujan sebelum dan sesudah dilakukan koreksi terhadap raw data reflektivitas radar cuaca band $\mathrm{C}$ serta membandingkan kemampuan algoritma koefisien a dan $\beta$ untuk koreksi atenuasi raw data reflektivitas menurut Battan, Harrison serta Krämer dan Verworn untuk mengetahui algoritma terbaik dalam menghasilkan informasi estimasi curah hujan yang akurat pada sistem radar cuaca di Stasiun Meteorologi Juanda. Penelitian ini diharapkan memiliki manfaat adanya peningkatan akurasi estimasi curah hujan pada radar cuaca band $\mathrm{C}$ di Stasiun Meteorologi Juanda Sidoarjo.

\section{Data}

Beberapa data yang digunakan di dalam penelitian ini yaitu raw data reflektivitas $(\mathrm{dBz})$ saat terjadi hujan baik dengan intensitas ringan sampai dengan sangat lebat pada bulan November 2018 sampai dengan Maret 2019 dari Stasiun Meteorologi Juanda Sidoarjo Jawa Timur, data freezing level rata-rata bulanan selama 10 tahun (2010 - 2019) saat bulan November - Maret, data tinggi dasar awan rata-rata bulan November 2018 - Maret 2019, data curah hujan hasil pengukuran penakar hujan tipping bucket per 5 menit dan 10 menit yang terpasang pada AAWS, AWS dan ARG di 74 titik yang berada dalam radius $150 \mathrm{~km}$ dari lokasi radar cuaca band C Stasiun Meteorologi Juanda Sidoarjo Jawa Timur serta data curah hujan hasil pengukuran observatorium pada bulan November 2018 sampai dengan Maret 2019 di delapan Stasiun BMKG di Jawa Timur.

Radar cuaca band C polarisasi tunggal di Stasiun Meteorologi Juanda Sidoarjo Jawa Timur dipilih untuk menjadi lokasi penelitian koreksi atenuasi yang disebabkan gangguan meteorologi berupa hujan. Pemilihan tersebut didasarkan pada operasional radar cuaca di Stasiun Meteorologi Juanda yang memiliki kontinuitas data yang baik secara temporal dan gangguan (clutter) non meteorologi terutama yang diakibatkan interferensi yaitu gangguan dari peralatan yang menggunakan frekuensi yang sama dengan radar cuaca. Lokasi penelitian ditunjukkan pada Gambar 1 berikut ini:

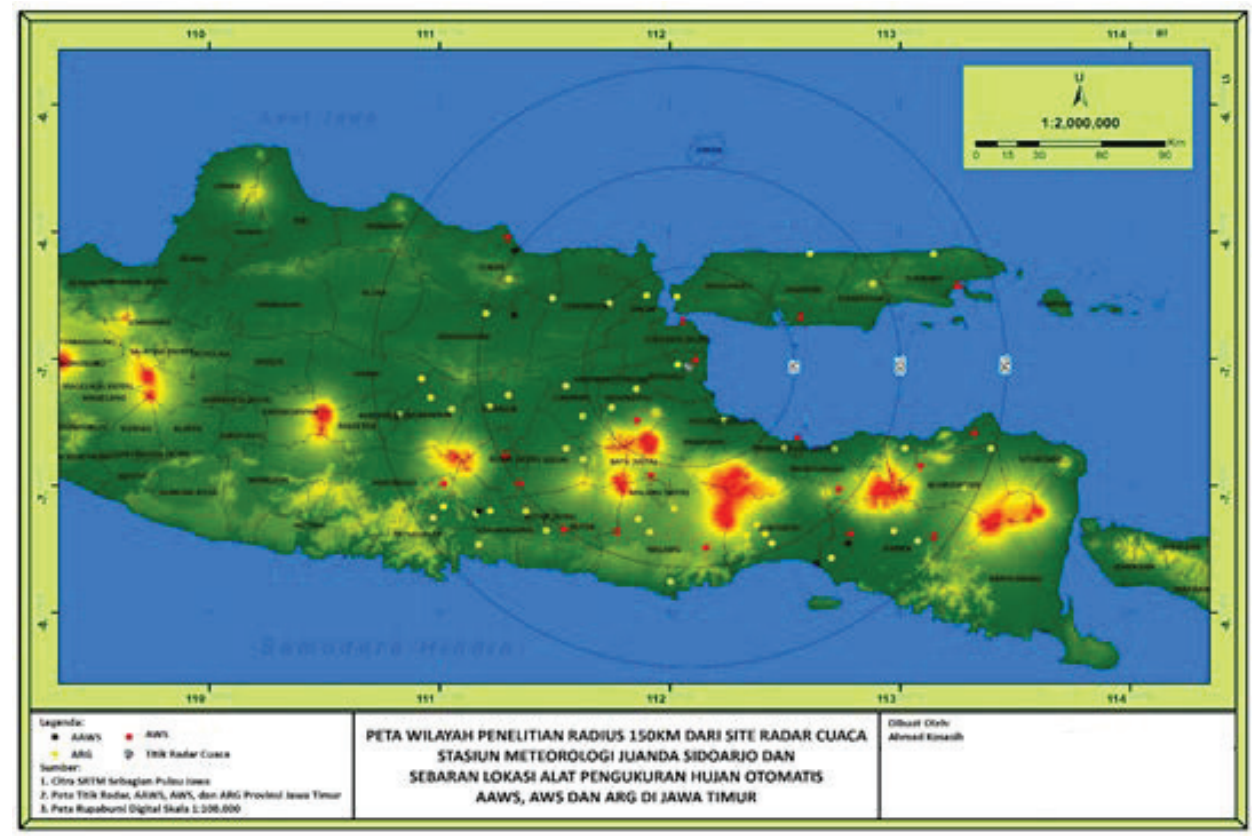

Gambar 1

Wilayah penelitian 


\section{Metode}

Koreksi atenuasi dilakukan untuk memperbaiki nilai reflektivitas $(\mathrm{dBz})$ yang berkurang karena adanya peredaman kekuatan sinyal saat proses pemindaian data baik pada saat sinyal dipancarkan maupun pada saat kembali ke sistem radar cuaca (specific twoway attenuation) hal tersebut terjadi akibat sinyal melewati objek meteorologi berupa air hujan. Semakin besar intensitas curah hujan yang dilewati sinyal dari radar cuaca, maka kemungkinan terjadinya pelemahan kekuatan sinyal akan semakin besar pula. Intensitas curah hujan didapatkan dari besarnya reflektivitas $(\mathrm{dBz})$ dengan menggunakan relasi antara Z-R, hal yang sama hubungan antara intensitas curah hujan (R) dalam $\mathrm{mm} \mathrm{jam}^{-1}$ dengan besarnya atenuasi $(\delta \mathrm{A} / \delta \mathrm{r})$ dalam satuan $\mathrm{db}$ $\mathrm{km}^{-1}$ terhadap kekuatan sinyal saat dipancarkan dan kembali sebagai nilai reflektivitas ( $\mathrm{dBz})$ ke sistem radar cuaca (specific two-way attenuation). Koreksi atenuasi menggunakan metode ZATC dilakukan pada setiap gate sepanjang ray path dari beam radar yang termasuk ke dalam sample volume pada saat pemindaian data oleh radar cuaca. Metode tersebut dikembangkan Hitschfeld dan Bordan (1954) dengan nilai koefisien a dan $\beta$ diperoleh dari Battan (1973). Algoritma $C$ band power law menggunakan nilai koefisien alpha $(\mathrm{a}) 0.0044$ dan nilai koefisien beta $(\beta)$ 1.17; algoritma $C$ band linear menggunakan nilai koefisien alpha ( $\alpha) 0.0062$ dan nilai koefisien beta $(\beta)$ 1.0; algoritma dari Harrison (2000) menggunakan nilai koefisien alpha (a) 0.00914 dan nilai koefisien beta ( $\beta$ ) 1.17 serta algoritma yang dikembangkan Krämer dan Verworn (2008) dengan nilai koefisien alpha (a) 0.0334 dan nilai koefisien beta ( $\beta$ ) 1.12 . Keempat algoritma koreksi atenuasi tersebut dipakai untuk memperbaiki raw data radar band C dari gangguan meteorologi berupa hujan sehingga diperoleh raw data yang sudah terkoreksi sebelum dilakukan pengolahan lebih lanjut berupa estimasi curah hujan dengan persamaan Marshall-Palmer.

Koreksi atenuasi dengan algoritma linear dan power law nilai koefisien a dan $\beta$ (Battan) yang diterapkan pada algoritma koreksi atenuasi metode ZATC dibatasi untuk nilai maksimum spesifik atenuasi $\left(\delta \mathrm{A}_{\max } / \delta \mathrm{r}\right)$ (maximum two-way specific attenuation) sebesar hanya $5 \mathrm{db} \mathrm{km}^{-1}$. Jika saat proses perhitungan atenuasi gate by gate dalam jarak (r) pada satu ray path didapatkan nilai di atas $5 \mathrm{db} \mathrm{km}^{-1}$ maka nilai atenuasinya akan tetap sebesar $5 \mathrm{db} \mathrm{km}^{-1}$ sedangkan jika nilai perhitungan di bawah threshold $\left(5 \mathrm{db} \mathrm{km}^{-1}\right)$ maka besaran atenuasinya sesuai dengan hasil perhitungan. Batasan atau threshold untuk nilai total atenuasi maksimum (maximum two-way total attenuation) adalah sebesar $20 \mathrm{db}\left(\mathrm{A}_{\max }\right)$. Jika nilai total maksimum atenuasi $\left(\mathrm{A}_{\max }\right)$ antar gate di akhir perhitungan satu ray path lebih besar dari threshold yang telah ditentukan $\left(\mathrm{A}_{\max }>20 \mathrm{db}\right)$ maka akan dilakukan perhitungan ulang menggunakan nilai offset reflektivitas tetap $(\Delta \mathrm{dBz})$ untuk menghitung semua nilai reflektivitas $(\mathrm{dBz})$ hasil pengukuran radar $\left(\mathrm{dBz}=\mathrm{dBz}_{\text {Meas }}+\Delta \mathrm{dBz}\right)$ pada proses estimasi curah hujan $\left(Z=a R^{b}\right)$. Koreksi nilai reflektivitas ( $\mathrm{dBz}$ ) selesai jika nilai total atenuasi $\mathrm{A} \leq \mathrm{A}_{\max }$ dalam satu ray path.

Proses koreksi atenuasi dengan algoritma power law yang diterapkan dengan koefisien a dan $\beta$ Harrison diberikan batasan untuk nilai maksimum spesifik atenuasi $\left(\delta \mathrm{A}_{\max } / \delta \mathrm{r}\right)$ maupun nilai total atenuasi maksimum $\left(\mathrm{A}_{\max }\right)$ sesuai hasil penelitian Battan. Koreksi atenuasi dengan algoritma power law yang diterapkan dengan koefisien a dan $\beta$ Krämer dan Verworn diberikan batasan nilai maksimum spesifik atenuasi $\left(\delta \mathrm{A}_{\max } / \delta \mathrm{r}\right)$ sesuai hasil penelitian Battan, sedangkan total atenuasi maksimum $\left(\mathrm{A}_{\text {max }}\right)$ sebesar $20 \mathrm{db}$ merupakan hasil modifikasi Jacobi \& Heistermann (2016) dan memberikan nilai maksimum reflektivitas $\left(\mathrm{dBz}_{\text {corr, max }}\right) 59$, artinya ketika diaktifkan $\mathrm{dBz}_{\text {corr, max }}$ maka nilai reflektivitas yang bernilai diatas $59 \mathrm{dBz}$ tidak dilakukan koreksi atenuasi atau atenuasi bernilai nol $\mathrm{db} \mathrm{km}^{-1}$.

Pengolahan koreksi atenuasi menerapkan wilayah koreksi hanya sebatas gate yang berada di bawah freezing level $\left(0^{\circ} \mathrm{C}\right)$ artinya bahwa yang akan dilakukan proses koreksi atenuasi hanya untuk hujan. Ketinggian rata-rata freezing level dari hasil pengamatan udara atas di Stasiun Meteorologi Juanda adalah $4.9 \mathrm{~km}$ untuk bulan November sampai dengan Maret dalam kurun waktu 10 tahun (2010-2019). Hasil dari koreksi 
raw data ini adalah raw data baru yang sudah terkoreksi dari gangguan meteorologi (hujan) dan selanjutnya dapat dilakukan perhitungan estimasi curah hujan dengan persamaan model relasi Z-R Marshall-Palmer (Z=200R $\left.{ }^{1.6}\right)$.

\section{HASIL DAN PEMBAHASAN}

Hasil penelitian yang dilakukan secara umum mendukung kajian yang dilakukan oleh beberapa peneliti lain yaitu kajian oleh Harrison, Driscoll \& Kitchen (2000), Jacobi \& Heistermann (2016) dan Krämer \& Verworn (2008). Ada sebanyak 45 lokasi penakar hujan tipping bucket yang terpasang pada AAWS, AWS dan ARG dengan radius $150 \mathrm{~km}$ dari radar cuaca band C Stasiun Meteorologi Juanda yang dapat dipergunakan untuk mengevaluasi kemampuan estimasi curah hujan dari radar cuaca dengan jumlah hari yang bervariasi. Kisaran jumlah hasil evaluasi kemampuan estimasi radar cuaca dengan proses koreksi atenuasi dan tanpa koreksi atenuasi setiap lokasi yaitu antara 1 - 35 hari. Secara keseluruhan, persentase tingkat kesalahan terkecil (RMSE) dalam perolehan hasil estimasi curah hujan oleh radar cuaca tanpa dilakukan koreksi atenuasi terlebih dahulu adalah sebesar $70,8 \%$ yang berada pada 45 lokasi dalam radius $150 \mathrm{~km}$, sedangkan jika pada raw data dilakukan proses koreksi atenuasi dengan koefisien a dan $\beta$ dari Battan, Harrison, maupun Krämer dan Verworn maka persentase nilai RMSE-nya bertambah sebesar $29.2 \%$. Penambahan akurasi estimasi curah hujan setelah dilakukan koreksi atenuasi terhadap raw data sesuai dengan apa yang dihasilkan oleh Harrison, Driscoll \& Kitchen (2000) maupun Jacobi \& Heistermann (2016) dan Krämer \& Verworn (2008) meskipun presentase penambahan akurasi akan berbeda.

Perbandingan data persentase RMSE antara data penakar hujan tipping bucket dengan estimasi curah hujan dari radar cuaca setiap lokasi tipping bucket yang terpasang pada AAWS, AWS dan ARG se Jawa Timur dalam radius $150 \mathrm{~km}$ dari radar cuaca band C Stasiun Meteorologi Juanda dengan proses tahapan koreksi atenuasi menggunakan koefisien a dan $\beta$ dari Battan (linear dan power law), Harrison, maupun Krämer dan Verworn serta pengolahan tanpa dilakukan koreksi atenuasi dapat dilihat pada Tabel 2 .

Tabel 2

Persentase RMSE estimasi curah hujan radar cuaca dengan dilakukan koreksi atenuasi dan tanpa koreksi atenuasi

\begin{tabular}{|c|c|c|c|c|c|c|c|c|}
\hline \multirow[b]{3}{*}{ No } & \multirow[b]{3}{*}{ 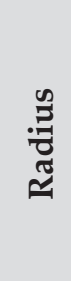 } & \multirow[b]{3}{*}{ Lokasi } & \multicolumn{6}{|c|}{ Persentase RMSE (\%) } \\
\hline & & & \multirow[b]{2}{*}{ 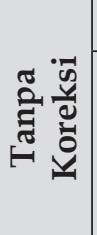 } & \multicolumn{5}{|c|}{ Koreksi Atenuasi } \\
\hline & & & & 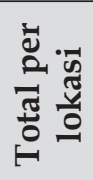 & $\frac{-\sqrt{7}}{0}$ & $\begin{array}{c}5 \\
0 \\
0 \\
\vdots \\
\vdots \\
5 \\
5 \\
5\end{array}$ & 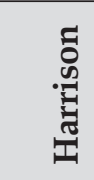 & 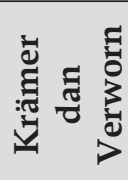 \\
\hline 1 & 50 & ARG Socah, Kab. Bangkalan & 90 & 10 & 3.3 & 6.7 & 0 & 0 \\
\hline 2 & 50 & ARG Lamongan, Kab. Lamongan & 100 & 0 & 0 & 0 & 0 & 0 \\
\hline 3 & 50 & AWS Mojokerto, Kab. Mojokerto & 81 & 19 & 0 & 9.5 & 9.5 & 0 \\
\hline 4 & 50 & ARG Sruni Gedangan, Kab. Sidoarjo & 60 & 40 & 14.3 & 0 & 5.7 & 20 \\
\hline 5 & 50 & AWS Maritim Perak II, Kota Surabaya & 83.3 & 16.7 & 5.6 & 11.1 & 0 & 0 \\
\hline 6 & 50 & $\begin{array}{l}\text { AWS Digi Stamet Juanda Surabaya, Kota } \\
\text { Surabaya }\end{array}$ & 100 & 0 & 0 & 0 & 0 & 0 \\
\hline 7 & 100 & ARG Mojowarno, Kab. Jombang & 96.6 & 3.4 & 0 & 0 & 3.4 & 0 \\
\hline 8 & 100 & ARG Kediri, Kab. Kediri & 93.3 & 6.7 & 0 & 6.7 & 0 & 0 \\
\hline 9 & 100 & AWS Kandat, Kab. Kediri & 93.3 & 6.7 & 0 & 0 & 0 & 6.7 \\
\hline
\end{tabular}




\begin{tabular}{|c|c|c|c|c|c|c|c|c|}
\hline \multirow[b]{3}{*}{ No } & \multirow[b]{3}{*}{ 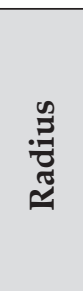 } & \multirow[b]{3}{*}{ Lokasi } & \multicolumn{6}{|c|}{ Persentase RMSE (\%) } \\
\hline & & & \multirow[b]{2}{*}{ 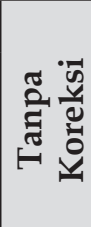 } & \multicolumn{5}{|c|}{ Koreksi Atenuasi } \\
\hline & & & & 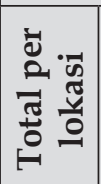 & 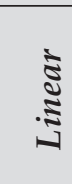 & $\mid \begin{array}{ll}0 & 1 \\
0 & 0 \\
0 & 0 \\
0 & 0 \\
1 & 3\end{array}$ & 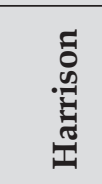 & 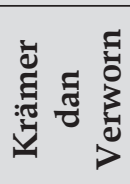 \\
\hline 10 & 100 & ARG Pronojiwo, Kab. Lumajang & 33.3 & 66.7 & 0 & 0 & 0 & 66.7 \\
\hline 11 & 100 & ARG Pasrujambe, Kab. Lumajang & 100 & 0 & 0 & 0 & 0 & 0 \\
\hline 12 & 100 & ARG Tajinan, Kab. Malang & 93.5 & 6.5 & 6.5 & 0 & 0 & 0 \\
\hline 13 & 100 & ARG Nganjuk, Kab. Nganjuk & 100 & 0 & 0 & 0 & 0 & 0 \\
\hline 14 & 100 & ARG SMPK Nganjuk, Kab. Nganjuk & 80 & 20 & 0 & 0 & 16.7 & 3.3 \\
\hline 15 & 100 & ARG Pakong, Kab. Pamekasan & 50 & 50 & 0 & 16.7 & 33.3 & 0 \\
\hline 16 & 100 & ARG Triwong Kidul, Kab. Probolinggo & 90.5 & 9.5 & 0 & 0 & 4.8 & 4.8 \\
\hline 17 & 100 & ARG Pajarakan Kulon, Kab. Probolinggo & 85 & 15 & 0 & 5 & 5 & 5 \\
\hline 18 & 100 & $\begin{array}{l}\text { AWS Pelabuhan Probolinggo, Kab. } \\
\text { Probolinggo }\end{array}$ & 100 & 0 & 0 & 0 & 0 & 0 \\
\hline 19 & 100 & ARG Sampang, Kab. Sampang & 88.9 & 11.1 & 0 & 0 & 0 & 11.1 \\
\hline 20 & 100 & AWS Sampang, Kab. Sampang & 100 & 0 & 0 & 0 & 0 & 0 \\
\hline 21 & 100 & ARG Widang, Kab. Tuban & 88.9 & 11.1 & 0 & 11.1 & 0 & 0 \\
\hline 22 & 100 & ARG Tuban, Kab. Tuban & 70.4 & 29.6 & 7.4 & 3.7 & 7.4 & 11.1 \\
\hline 23 & 100 & ARG Ngajum, Kota Malang & 0 & 100 & 0 & 0 & 0 & 100 \\
\hline 24 & 100 & AWS Staklim Malang, Kota Malang & 0 & 100 & 0 & 0 & 8.3 & 91.7 \\
\hline 25 & 150 & ARG Kademangan, Kab. Blitar & 33.3 & 66.7 & 0 & 0 & 0 & 66.7 \\
\hline 26 & 150 & ARG Srengat, Kab. Blitar & 0 & 100 & 0 & 0 & 0 & 100 \\
\hline 27 & 150 & ARG Cerme, Kab. Bondowoso & 70 & 30 & 0 & 0 & 10 & 20 \\
\hline 28 & 150 & ARG Jatibanteng, Kab. Bondowoso & 100 & 0 & 0 & 0 & 0 & 0 \\
\hline 29 & 150 & ARG Pinang Pahit, Kab. Bondowoso & 0 & 100 & 0 & 0 & 100 & 0 \\
\hline 30 & 150 & AWS Bondowoso, Kab. Bondowoso & 100 & 0 & 0 & 0 & 0 & 0 \\
\hline 31 & 150 & ARG Kencong, Kab. Jember & 64.7 & 35.3 & 5.9 & 11.8 & 5.9 & 11.8 \\
\hline 32 & 150 & ARG Wirolegi, Kab. Jember & 50 & 50 & 0 & 5 & 30 & 15 \\
\hline 33 & 150 & AWS Tanggul, Kab. Jember & 100 & 0 & 0 & 0 & 0 & 0 \\
\hline 34 & 150 & AAWS Yosowilangun, Kab. Lumajang & 0 & 100 & 0 & 0 & 33.3 & 66.7 \\
\hline 35 & 150 & ARG Caruban, Kab. Madiun & 100 & 0 & 0 & 0 & 0 & 0 \\
\hline 36 & 150 & ARG Kartoharjo, Kab. Madiun & 94.1 & 5.9 & 0 & 0 & 5.9 & 0 \\
\hline 37 & 150 & ARG SMPK Sebayi Gemarang, Kab. Madiun & 62.5 & 37.5 & 0 & 0 & 12.5 & 25 \\
\hline 38 & 150 & ARG Sitiarjo, Kab. Malang & 52.9 & 47.1 & 5.9 & 17.6 & 11.8 & 11.8 \\
\hline 39 & 150 & ARG Ngawi, Kab. Ngawi & 100 & 0 & 0 & 0 & 0 & 0 \\
\hline 40 & 150 & AWS Panarukan, Kab. Situbondo & 50 & 50 & 0 & 0 & 50 & 0 \\
\hline 41 & 150 & ARG Dasuk, Kab. Sumenep & 40 & 60 & 0 & 0 & 20 & 40 \\
\hline 42 & 150 & AWS Digi Stamet Kalianget, Kab. Sumenep & 78.9 & 21.1 & 0 & 0 & 5.3 & 15.8 \\
\hline 43 & 150 & ARG SMPK Karangan, Kab. Trenggalek & 40 & 60 & 20 & 0 & 20 & 20 \\
\hline
\end{tabular}


Lanjutan Tabel 2

\begin{tabular}{|c|c|c|c|c|c|c|c|c|}
\hline \multirow[b]{3}{*}{ No } & \multirow[b]{3}{*}{ 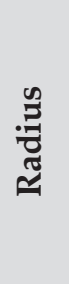 } & \multirow[b]{3}{*}{ Lokasi } & \multicolumn{6}{|c|}{ Persentase RMSE (\%) } \\
\hline & & & \multirow[b]{2}{*}{ 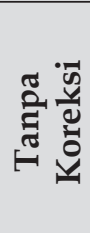 } & \multicolumn{5}{|c|}{ Koreksi Atenuasi } \\
\hline & & & & 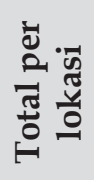 & 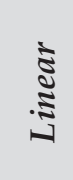 & 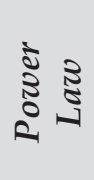 & 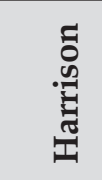 & 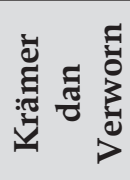 \\
\hline 44 & 150 & ARG Gondang, Kab. Tulungagung & 88.2 & 11.8 & 5.9 & 0 & 5.9 & 0 \\
\hline 45 & 150 & AWS Digi Stamet Tuban, Kab. Tuban & 83.3 & 16.7 & 0 & 0 & 5.6 & 11.1 \\
\hline \multicolumn{3}{|c|}{ Total persentase } & 70.8 & 29.2 & 1.7 & 2.3 & 9.1 & 16.1 \\
\hline
\end{tabular}

Sumber: Pengolahan (2019)

Berdasarkan jarak lokasi AAWS, AWS dan ARG dengan lokasi site radar cuaca maka persentase RMSE estimasi curah hujan tanpa koreksi atenuasi mengalami penurunan seiring dengan semakin jauh jaraknya dari titik radar cuaca, sedangkan persentase RMSE estimasi curah hujan dengan dilakukan koreksi atenuasi dengan menggunakan koefisien a dan $\beta$ dari
Battan (linear dan power law), Harrison, maupun Krämer dan Verworn terhadap raw data radar mengalami peningkatan seiring penambahan jarak dari lokasi radar cuaca band C Stasiun Meteorologi Juanda. Persentase RMSE estimasi curah hujan menurut jarak dari site radar cuaca pada masing-masing algoritma dapat dilihat pada Tabel 3.

Tabel 3

Persentase RMSE antara estimasi curah hujan dari radar cuaca yang dilakukan koreksi atenuasi dengan tanpa koreksi atenuasi berdasarkan jarak terhadap site radar cuaca band $\mathrm{C}$

Stasiun Meteorologi Juanda

\begin{tabular}{|c|c|c|c|c|c|c|}
\hline \multirow{2}{*}{$\begin{array}{l}\text { Jarak dari site } \\
\text { radar cuaca }(\mathbf{k m})\end{array}$} & \multicolumn{6}{|c|}{ Persentase RMSE (\%) } \\
\hline & $\begin{array}{c}\text { Tanpa } \\
\text { Koreksi }\end{array}$ & \begin{tabular}{|c|} 
Total Koreksi \\
Atenuasi
\end{tabular} & Linear & Power Law & Harrison & $\begin{array}{l}\text { Krämer dan } \\
\text { Verworn }\end{array}$ \\
\hline 50 & 85.7 & 14.3 & 3.9 & 4.6 & 2.5 & 3.3 \\
\hline 100 & 75.8 & 24.2 & 0.8 & 2.4 & 4.4 & 16.7 \\
\hline 150 & 62.3 & 37.7 & 1.8 & 1.6 & 15.0 & 19.2 \\
\hline
\end{tabular}

Sumber: Pengolahan (2019)

Terjadinya penurunan nilai akurasi estimasi curah hujan hasil pengamatan radar cuaca tanpa dilakukan koreksi terhadap raw data disebabkan oleh penurunan energi dari pulsa radar yang diterima kembali oleh radar cuaca sepanjang ray path dalam beam radar cuaca. Pengurangan energi yang disebabkan gangguan atenuasi akan terus bertambah seiring pertambahan jarak obyek hujan dengan posisi radar cuaca $\left(\mathrm{db} \mathrm{km}^{-1}\right)$.

Hasil pengolahan estimasi curah hujan radar cuaca band $\mathrm{C}$ dengan empat koefisien koreksi atenuasi dan tanpa koreksi atenuasi terhadap raw data radar cuaca menghasilkan 575 informasi uji kemampuan (korelasi dan RMSE) antara estimasi curah hujan dengan empat koefisien koreksi atenuasi dan tanpa koreksi atenuasi terhadap curah hujan hasil pengukuran langsung dari alat penakar hujan tipping bucket.

Lokasi persebaran AAWS, AWS dan ARG sejumlah 45 lokasi pada 24 Kabupaten/Kota se Jawa Timur memiliki karakteristik topografi wilayah yang berbeda. Wilayah yang berada di selatan dari site radar cuaca band C Stasiun Meteorologi Juanda merupakan wilayah perbukitan dan pegunungan sedangkan wilayah utara Jawa Timur merupakan dataran rendah. Gangguan atenuasi yang disebabkan oleh hujan dengan intensitas sangat lebat akan berbeda dengan hujan intensitas ringan. Hujan dengan intensitas lebat atau sangat lebat sangat berdampak terhadap penurunan nilai reflektivitas 
yang akhirnya menyebabkan penurunan nilai estimasi curah hujan secara kuantitatif.

ARG Sruni Gedangan Kabupaten Sidoarjo merupakan alat penakar hujan tipping bucket terdekat dengan lokasi radar cuaca band $\mathrm{C}$ Stasiun Meteorologi Juanda pada radius 50 $\mathrm{km}$, ARG tersebut menghasilkan 14 informasi RMSE antara estimasi curah hujan dari radar cuaca yang telah diproses koreksi atenuasi dengan data pengukuran hujan secara langsung dari total 35 informasi RMSE untuk 49 hari pengolahan raw data radar cuaca dan data curah hujan. Hasil pengolahan diperoleh RMSE estimasi dengan menerapkan koreksi atenuasi $40 \%$, dengan presentase tertinggi diperoleh koefisien a dan $\beta$ menurut Krämer dan Verworn sebesar 20\%, Battan (linear) sebesar $14.3 \%$ dan Harrison sebesar 5.7\%.

Tabel 4

Nilai RMSE estimasi curah hujan yang telah diterapkan koreksi atenuasi dengan nilai koefisien menurut Battan (linear dan power law), Harrison, serta Kramer dan Verworn pada ARG Sruni Gedangan Kab. Sidoarjo

\begin{tabular}{c|l|l|l|l|l|l|l|c}
\hline \multirow{2}{*}{ Tanggal } & \multicolumn{2}{|c|}{ Linear } & \multicolumn{2}{c|}{ Power Law } & \multicolumn{2}{c|}{ Harrison } & \multicolumn{2}{c}{ Krämer dan Verworn } \\
\cline { 2 - 8 } & Korelasi & RMSE & Korelasi & RMSE & Korelasi & RMSE & Korelasi & RMSE \\
\hline $25 / 12 / 2018$ & 0.999 & 7.369 & 0.999 & 7.24 & 0.999 & 6.129 & 1 & 2.35 \\
\hline
\end{tabular}

Sumber: Pengolahan (2019)

Pada tabel 4 tanggal 25 Desember 2018 sebagai studi kasus estimasi curah hujan dari radar cuaca dengan dilakukan koreksi sebelumnya, koefisien a dan $\beta$ menurut Krämer dan Verworn menghasilkan nilai RMSE sebesar 2.35 yang merupakan tingkat kesalahan terkecil dalam pengolahan data estimasi curah hujan di wilayah ARG Sruni Gedangan Kabupaten Sidoarjo dibandingkan dengan nilai koefisien a dan $\beta$ menurut Battan maupun Harrison. Secara spasial estimasi curah hujan dengan koreksi atenuasi menggunakan koefisien a dan $\beta$ menurut Krämer dan Verworn pada tanggal 25 Desember 2018 dapat dilihat pada Gambar 2 (a) dan 2 (b) sedangkan Gambar 3 menunjukkan grafik estimasi curah hujan

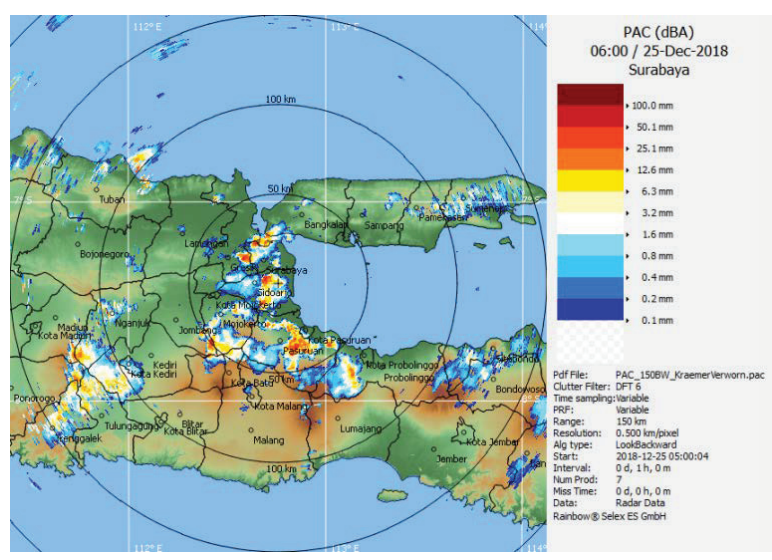

dari radar cuaca dibandingkan pengukuran langsung oleh tipping bucket.

Gambar 2 (a) memperlihatkan secara spasial bagaimana saat terjadi hujan di wilayah ARG Sruni Gedangan Kab. Sidoarjo. Gradasi warna pada legenda citra radar cuaca hasil perhitungan precipitation accumulation (PAC) jam 06.00 utc (13.00 wib) menunjukkan warna kuning sampai dengan warna coklat muda yang mendominasi sekitar wilayah Kabupaten Sidoarjo dengan estimasi curah hujan 6.3 - 50 $\mathrm{mm}$ jam $^{-1}$. Hasil perhitungan surface rainfall intensity (SRI) pada jam pengamatan radar cuaca 05.30 utc (12.30 wib) yang diperlihatkan oleh Gambar 2 (b) menunjukkan gradasi warna kuning hingga coklat dengan kisaran nilai estimasi curah hujan 6.3 - $100 \mathrm{~mm} \mathrm{jam}^{-1}$.

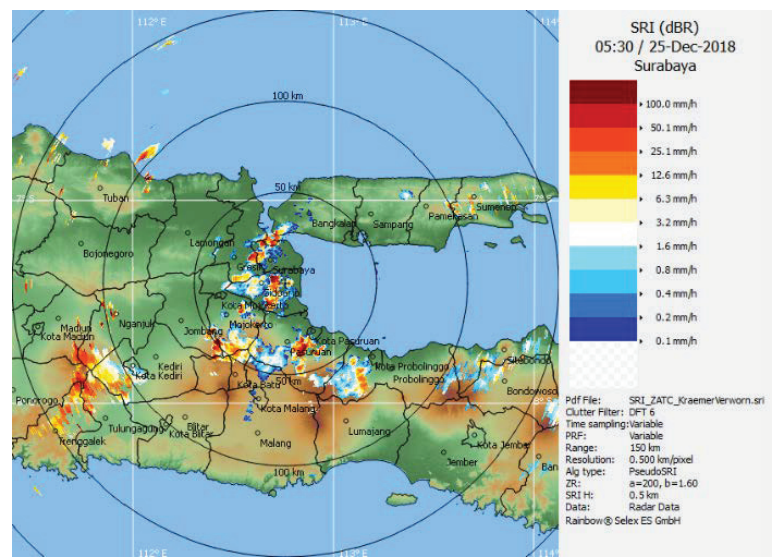

Gambar 2.

(a) Hasil Precipitation Accumulation (PAC) jam 06.00 utc (b) SRI jam 05.30 utc dengan koreksi atenuasi menggunakan nilai koefisien menurut Kramer dan Verworn tanggal 25 Desember 2018 


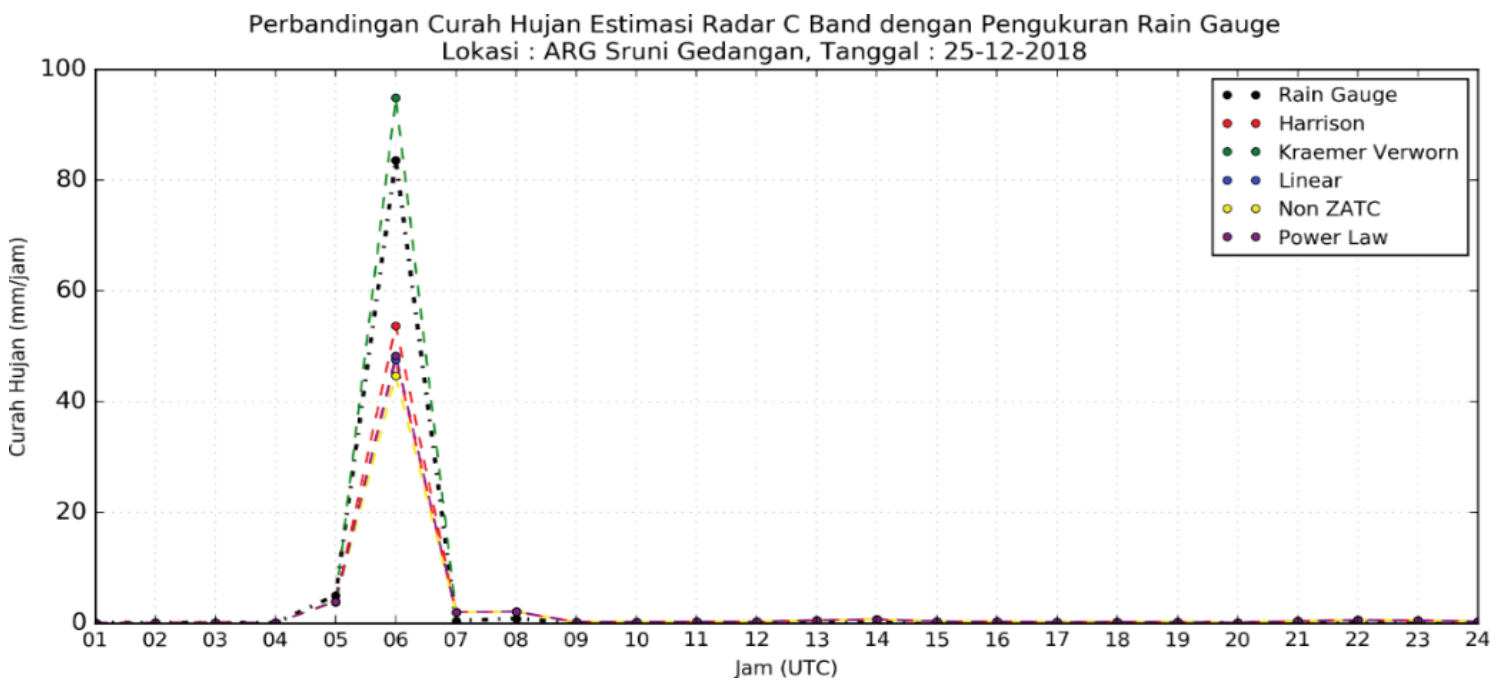

Gambar 3.

Hasil perbandingan estimasi PAC radar cuaca dengan akumulasi pengukuran tipping bucket per 1 jam ARG Sruni Gedangan Kab. Sidoarjo tanggal 25 Desember 2018

Pada tanggal 25 Desember 2018 hasil pengukuran curah hujan tipping bucket untuk akumulasi jam 06.00 utc (13.00 wib) tercatat sebesar $83.6 \mathrm{~mm} \mathrm{jam}^{-1}$ yang artinya pada rentang waktu 05.10 - 06.00 utc telah terjadi hujan dengan intensitas sangat lebat yang menyebabkan pelemahan energi pada pulsa radar cuaca band $\mathrm{C}$ sehingga nilai reflektivitas (dBz) yang dihasilkan tidak sesuai dengan kondisi sebenarnya.

Estimasi curah hujan dari radar cuaca saat dilakukan koreksi atenuasi dengan nilai koefisien a dan $\beta$ menurut Battan (linear dan power law) dan Harrison untuk akumulasi jam 06.00 utc adalah sebesar $47.592 \mathrm{~mm}$ jam${ }^{1}$ (linear), $48.225 \mathrm{~mm} \mathrm{jam}^{-1}$ (power law) dan Harrison sebesar $53.689 \mathrm{~mm} \mathrm{jam}^{-1}$. Hasil estimasi curah hujan ketika dilakukan koreksi atenuasi dengan koefisien a dan $\beta$ menurut
Krämer dan Verworn menjadi sebesar 94.819 $\mathrm{mm} \mathrm{jam}^{-1}$ dimana hasil ini lebih mendekati nilai hasil pengukuran curah hujan dari tipping bucket yang terpasang pada ARG Sruni Gedangan Kab. Sidoarjo.

AWS Stasiun Klimatologi Malang di Kota Malang menghasilkan 24 informasi RMSE estimasi curah hujan yang telah dilakukan koreksi atenuasi dari 49 hari pengolahan raw data radar cuaca dan data curah hujan tipping bucket. Hasil pengolahan diperoleh RMSE estimasi dengan menerapkan koreksi atenuasi sebesar $100 \%$, dengan presentase tertinggi diperoleh koefisien $\alpha$ dan $\beta$ menurut Krämer dan Verworn sebesar 91.7\% dan Harrison sebesar $8.3 \%$. Tabel 5 memperlihatkan hasil korelasi dan RMSE estimasi curah hujan radar dengan menerapkan koreksi atenuasi pada AWS Stasiun Klimatologi Malang, Kota Malang pada tanggal 10 Februari 2019.

Tabel 5

Nilai RMSE estimasi curah hujan yang telah diterapkan koreksi atenuasi dengan nilai koefisien menurut Battan (linear dan power law), Harrison, serta Kramer dan Verworn pada AWS Staklim Malang di Kota Malang

\begin{tabular}{c|l|l|l|l|l|l|l|c}
\hline \multirow{2}{*}{ Tanggal } & \multicolumn{2}{|c|}{ Linear } & \multicolumn{2}{c|}{ Power Law } & \multicolumn{2}{c|}{ Harrison } & \multicolumn{2}{c}{ Krämer dan Verworn } \\
\cline { 2 - 9 } & Korelasi & RMSE & Korelasi & RMSE & Korelasi & RMSE & Korelasi & RMSE \\
\hline $10 / 02 / 2019$ & 0.978 & 4.926 & 0.98 & 4.918 & 0.992 & 4.535 & 0.975 & 1.446 \\
\hline
\end{tabular}


Pada studi kasus penerapan koreksi atenuasi untuk memperoleh estimasi curah
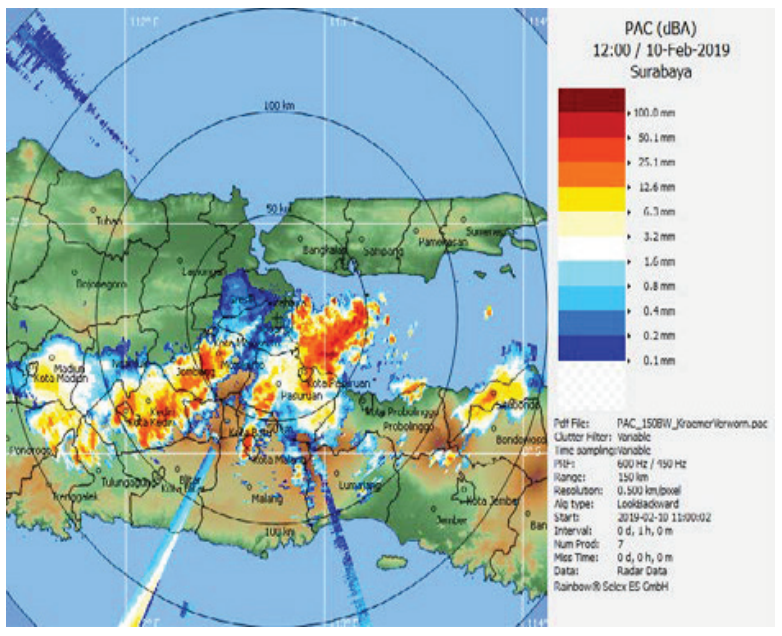

hujan dari radar cuaca untuk AWS Staklim Malang Kota

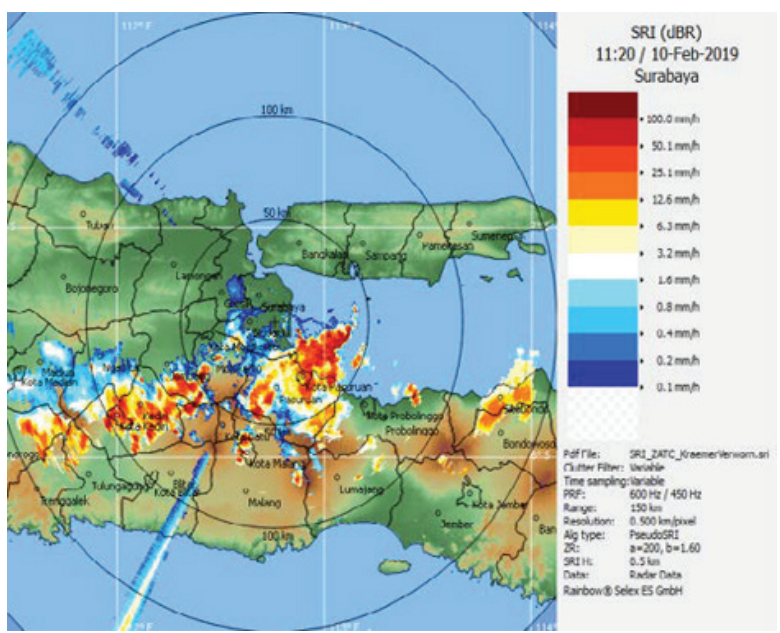

Gambar 4.

(a) Hasil Precipitation Accumulation (PAC) jam 12 utc (b) dengan koreksi atenuasi menggunakan nilai koefisien menurut Kramer dan Verworn tanggal 10 Februari 2019

Malang pada tanggal 10 Februari 2019, koefisien a dan $\beta$ menurut Krämer dan Verworn menghasilkan nilai RMSE sebesar 1.446 yang merupakan nilai terkecil dibandingkan dengan perhitungan yang dihasilkan oleh koefisien menurut Battan (linear dan power law) maupun Harrison. Secara spasial estimasi curah hujan dengan koreksi atenuasi menggunakan koefisien a dan $\beta$ menurut Krämer dan Verworn pada tanggal 10 Februari 2019 dapat dilihat pada Gambar 4 (a) dan 4 (b), sedangkan Gambar 5 menunjukkan grafik estimasi curah hujan dari radar cuaca dibandingkan pengukuran langsung oleh tipping bucket.

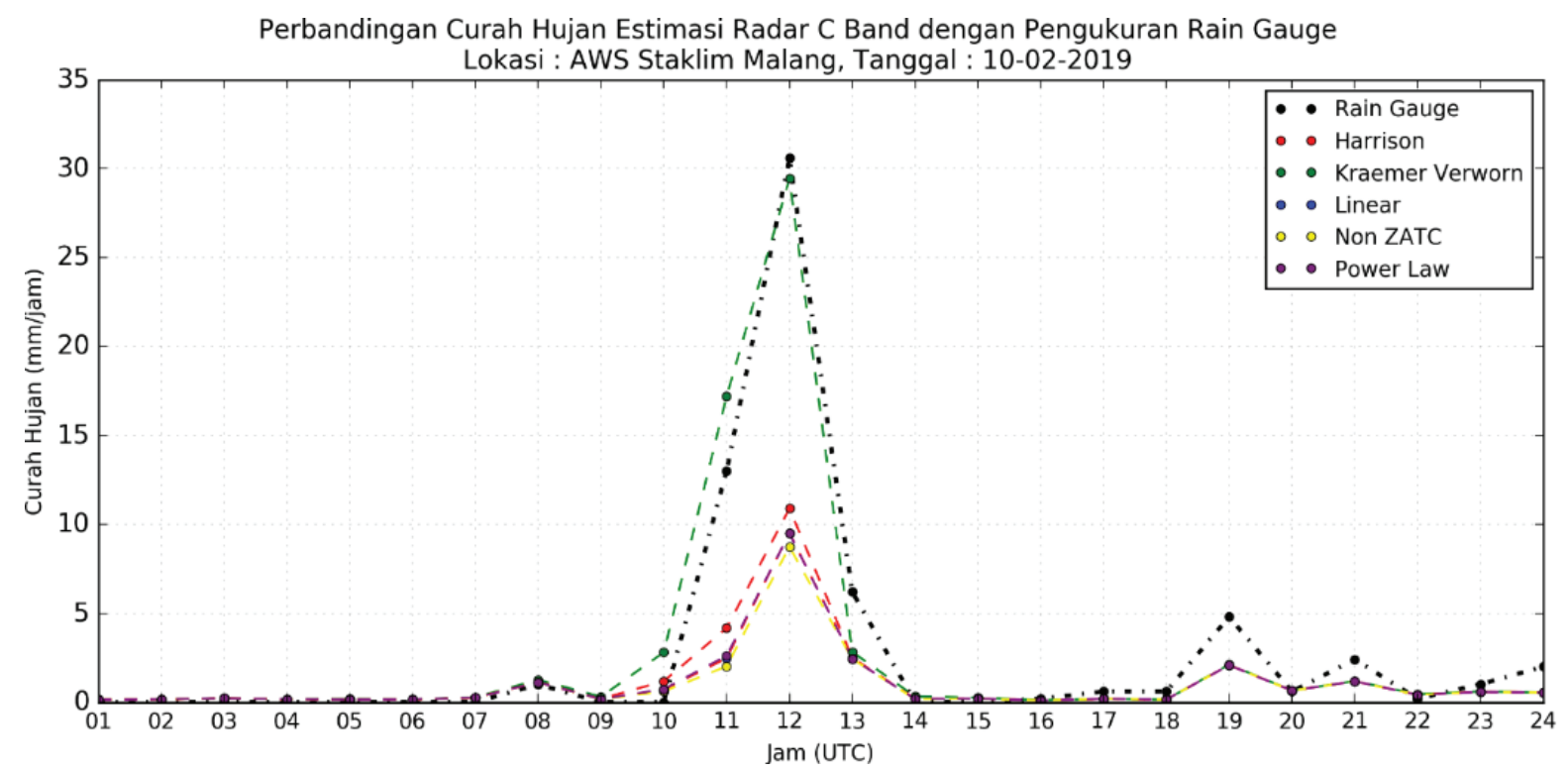

Gambar 5.

Hasil perbandingan estimasi PAC radar cuaca dengan akumulasi pengukuran tipping bucket per 1 jam AWS Staklim Malang Kota Malang tanggal 10 Februari 2019 
Hasil pengolahan estimasi curah hujan secara spasial berupa produk informasi precipitation accumulation (PAC) pada tanggal 10 Februari 2019 seperti pada Gambar 4 (a) memperlihatkan kondisi adanya gangguan (clutter) interferensi pada beberapa sektor pengamatan radar cuaca Stasiun Meteorologi Juanda. Produk informasi PAC jam 12.00 utc secara umum di beberapa Kabupaten/ Kota terjadi hujan dengan gradasi warna biru sampai dengan coklat muda, sedangkan khusus wilayah ARG Stasiun Klimatologi Malang, Kota Malang gradasi warna kuning dan coklat muda dengan estimasi curah hujan berkisar antara $6.3 \mathrm{~mm} \mathrm{jam}^{-1}$ sampai dengan $50 \mathrm{~mm} \mathrm{jam}^{-1}$ dan termasuk dalam klasifikasi intensitas curah hujan sedang sampai dengan sangat lebat, nilai reflektifitas estimasi curah hujan berkisar antara $38-48 \mathrm{dBz}$ sampai dengan $>58 \mathrm{dBz}$. Hasil perhitungan surface rainfall intensity (SRI) secara spasial pada jam pengamatan radar cuaca jam 11.20 utc dapat dilihat pada Gambar 4 (b).

Hasil pengukuran curah hujan tipping bucket untuk akumulasi tanggal 10 Februari 2019 jam 12.00 utc $(19.00 \mathrm{wib})$ tercatat sebesar $30.6 \mathrm{~mm} \mathrm{jam}^{-1}$. Hal ini menunjukkan bahwa pada rentang waktu 16.10 - 17.00 utc telah terjadi hujan dengan intensitas sangat lebat. Pelemahan energi pada pulsa radar cuaca band C karena terjadi hujan sangat lebat tidak hanya di wilayah sekitar AWS Stasiun Klimatologi Malang, Kota Malang tetapi sangat dimungkinkan di sepanjang arah penjalaran gelombang radar cuaca pada beam radar cuaca terjadi hujan dengan intensitas yang bervariasi seperti pada Gambar 4 (a) dan Gambar 4 (b) terlihat kondisi hujan di wilayah Kabupaten Pasuruan, Mojokerto hingga Kabupaten Sidoarjo.

Estimasi curah hujan dari radar cuaca saat dilakukan koreksi atenuasi dengan nilai koefisien a dan $\beta$ menurut Battan (linear dan power law) dan Harrison untuk akumulasi jam 12.00 utc adalah sebesar $9.506 \mathrm{~mm} \mathrm{jam}^{-1}$ (linear), $9.489 \mathrm{~mm} \mathrm{jam}^{-1}$ (power law) dan sebesar $10.888 \mathrm{~mm} \mathrm{jam}^{-1}$ (Harrison). Hasil estimasi curah hujan ketika dilakukan koreksi atenuasi dengan koefisien a dan $\beta$ menurut Krämer dan Verworn sebesar $29.44 \mathrm{~mm} \mathrm{jam}^{-1}$ lebih mendekati nilai hasil pengukuran curah hujan dari tipping bucket yang terpasang pada AWS Stasiun Klimatologi Malang, Kota Malang.

Kemampuan koreksi atenuasi masingmasing nilai koefisien a dan $\beta$ menurut Battan (linear dan power law), Harrison serta Krämer dan Verworn yang diterapkan pada algoritma Z-based attenuation correction (ZATC) dibandingkan satu sama lain dalam upaya memperbaiki hasil estimasi curah hujan dari radar cuaca band $\mathrm{C}$. Hasil pengolahan estimasi curah hujan dengan dilakukan koreksi raw data menghasilkan penambahan persentase keseluruhan RMSE estimasi curah hujan sebesar $29.2 \%$ pada 45 lokasi tipping bucket yang dihitung untuk radius $150 \mathrm{~km}$ dari site radar cuaca band C. Jumlah tersebut merupakan penggabungan dari empat nilai koefisien koreksi atenuasi yang berbeda. Nilai koefisien a dan $\beta$ dari Krämer dan Verworn memiliki nilai persentase RMSE tertinggi dengan nilai sebesar $16.1 \%$ selanjutnya yaitu koefisien a dan $\beta$ dari Harrison sebesar 9.1\% sedangkan koefisien a dan $\beta$ dari Battan (linear dan power law) adalah masing-masing sebesar $1.7 \%$ dan $2.3 \%$. Hasil penelitian Jacobi \& Heistermann (2016) menunjukkan kesesuaian bahwa kinerja koefisien a dan $\beta$ dari Krämer dan Verworn lebih baik melakukan koreksi atenuasi dibandingkan koefisien a dan $\beta$ menurut Harrison.

\section{SIMPULAN}

Berdasarkan hasil analisis maka dapat disimpulkan bahwa pada proses estimasi curah hujan setelah dilakukan koreksi terhadap raw data reflektivitas radar cuaca band $\mathrm{C}$ menghasilkan nilai akurasi yang lebih baik dibandingkan dengan hasil estimasi curah hujan sebelum diterapkan tahapan koreksi atenuasi menggunakan koefisien $\alpha$ dan $\beta$ menurut Battan (linear dan power law), Harrison serta Krämer dan Verworn.

Dari semua algoritma koreksi atenuasi yang dipergunakan pada penelitian ini diketahui bahwa nilai koefisien a dan $\beta$ untuk koreksi atenuasi raw data reflektivitas $(\mathrm{dBz})$ radar cuaca yang terbaik untuk dapat 
diterapkan dalam memperoleh estimasi curah hujan yang lebih akurat yaitu dengan menggunakan koefisien a dan $\beta$ menurut Krämer dan Verworn sementara itu hasil penambahan akurasi terendah diperoleh pada algoritma koreksi atenuasi menurut Battan (linear).

Saran dari penulis untuk penelitian lebih lanjut adalah sebaiknya dilakukan koreksi terhadap gangguan clutter selain dilakukan koreksi atenuasi karena hujan terhadap raw data reflektivitas radar cuaca sebelum dilakukan pengolahan data untuk memperoleh informasi estimasi curah hujan, agar diperoleh tingkat akurasi estimasi yang lebih baik maka menggunakan beberapa model relasi Z-R yang sesuai dengan karakteristik hujan pada musim hujan maupun peralihan musim (pancaroba) di wilayah tersebut.

\section{UCAPAN TERIMA KASIH}

Penulis mengucapkan terima kasih yang tulus kepada Badan Meteorologi, Klimatologi, dan Geofisika atas bantuannya dalam menyelesaikan penelitian ini, khususnya Pusat Pendidikan dan Pelatihan BMKG, Stasiun Meteorologi Juanda Sidoarjo serta rekanrekan BMKG dan pihak lain yang memberikan dukungan dan bantuan untuk publikasi hasil penelitian.

\section{DAFTAR PUSTAKA}

Atlas, D. and Ulbrich, C. W. (1977) 'Path and Area Integrated Rainfall Measurement by Microwave Attenuation 1-3 cm Band', Journal of Applied Meteorology, 16(12), pp. 13221331.

Badan Meteorologi Klimatologi dan Geofisika (2010) 'Press Release Kondisi Cuaca Ekstrim dan Iklim Tahun 2010 2011'. Jakarta, p. 53.

Bringi, V. N. et al. (1990) 'An Examination of Propagation Effects in Rainfall on Radar Measurements at Microwave Frequencies', Journal of Atmospheric and Oceanic Technology, 7(12), pp. 829-840.
Bringi, V. N., Keenan, T. D. and Chandrasekar, V. (2001) 'Correcting C-Band Radar Reflectivity and Differential Reflectivity Data for Rain Attenuation : A Self-Consistent Method With Constraints', IEEE Transaction on Geoscience and Remote Sensing, 39(9), pp. 1906-1915.

Friedrich, K., Hagen, M. and Einfalt, T. (2006) 'A Quality Control Concept for Radar Reflectivity, Polarimetric Parameters, and Doppler Velocity', Journal of Atmospheric and Oceanic Technology, 23(7), pp. 865-887.

Fukao, S. and Hamazu, K. (2014) Radar for Meteorological and Atmospheric. First. Tokyo, Jepang: Springer. doi: 10.1007/978-4-431-54334-3.

G. Park, S. et al. (2005) 'Correction of Radar Reflectivity and Differential Reflectivity for Rain Attenuation at X Band . Part I: Theoretical and Empirical Basis', Journal of Atmospheric and Oceanic Technology, 22(11), pp. 1621-1632.

Gabella, M. and Notarpietro, R. (2002) 'Ground clutter characterization and elimination in mountainous terrain', in Proceedings of ERAD, pp. 305-311.

Hannesen, R. and Loffler-Mang, M. (1998) 'Improvements of quantitative rain measurements with a C-band Doppler radar through consideration of orographically induced partial beam screening', Proc. Cost 75 Seminar, pp. 511-519.

Hardaker, P. J., Holt, A. R. and Collier, C. G. (1995) 'A melting-layer model and its use in correcting for the bright band in single-polarization radar echoes', Quarterly Journal of the Royal Meteorological Society, 121, pp. 495525. doi: 551.501.81:551.574.14.

Harrison, D. L., Driscoll, S. J. and Kitchen, M. (2000) 'Improving Precipitation Estimates from Weather Radar using Quality Control and Correction 
Techniques',

Meteorological

Applications, 6, pp. 135-144.

Hitschfeld, W. and Bordan, J. (1954) 'Errors Inherent in The Radar Measurement of Rainfall at Attenuating Wavelengths', Journal of Meteorology, 11(02), pp. 58-67.

Hubbert, J. C., Dixon, M. and Ellis, S. M. (2009) 'Weather Radar Ground Clutter . Part II : Real-Time Identification and Filtering', Journal of Atmospheric and Oceanic Technology, 26(7), pp. 1181-1197. doi: 10.1175/2009JTECHA1160.1.

Jacobi, S. and Heistermann, M. (2016) 'Benchmarking attenuation correction procedures for six years of single-polarized C-band weather radar observations in South-West Germany', Geomatics, Natural Hazard And Risk. Taylor \& Francis, 7, pp. 1785-1799. doi: 10.1080/19475705.2016.1155080.

Kitchen, M., Brown, R. and Davies, A. G. (1994) 'Real-time correction of weather radar data for the effects of bright band, range and orographic growth in widespread precipitation', Quarterly Journal of the Royal Meteorological Society, 120, pp. 12311254. doi: 551.501.777:551.501.81:551 .577.51:681.2.08.

Krämer, S. and Verworn, H. R. (2008) 'Improved C-band radar data processing for real time control of urban drainage systems', in 11th International Conference on Urban Drainage. Edinburgh, Scotland, p. 10.

Mori, K. (2003) Hidrologi untuk Pengairan. Kesembilan. Edited by S. Sosrodarsono and K. Takeda. Jakarta: Pradnya Paramita.

Munawar (2016) Pemodelan Spasiotemporal Prediksi Curah Hujan Ekstrem
Berdasarkan Integrasi Data Radar Dan Satelit Cuaca Di Provinsi Jawa Timur. Gadjah Mada.

Olsen, R. L., Rogers, D. V. and Hodge, D. B. (1978) 'The aRb Relation in the Calculation of Rain Attenuation', IEEE Transactions on Antennas and Propagation, AP-26(03), pp. 318-329. doi: 0018-926X/78/0300-0318 \$00.75.

Rauber, R. M. and Nesbitt, S. W. (2018) Radar Meteorology. First. Chichester, UK: John Wiley \& Sons Ltd.

Rico-ramirez, M. A. (2012) 'Adaptive Attenuation Correction Techniques for C-Band Polarimetric Weather Radars', IEEE Transaction on Geoscience and Remote Sensing, 50(12), pp. 5061-5071. doi: 10.1109/ TGRS.2012.2195228.

Rinehart, R. E. (2004) Radar For Meteorologists. Fourth. Columbia, USA: Rinehart Publications.

Skolnik, M. (2008) Radar Hand Book. Third. Edited by J. Walden. New York: The McGraw-Hill Companies.

Smith, J. C. (1986) 'The Reduction of Error Caused by Bright Band in Quantitative Rainfall Measurements Made Using Radar', Journal of Atmospheric and Oceanic Technology, 3(March 1986), pp. 129-141.

Wardoyo, E. (2015) 'Radar Meteorologi: Pengantar Analisis Citra Radar Cuaca'. Jakarta, p. 315.

World Meteorological Organization (WMO) (2017) WMO No. 8 Guide to Meteorological Instruments and Methods of Observation. 2014th edn. Geneva, Switzerland: Chairperson, Publications Board World Meteorological Organization (WMO). 